\title{
Angiotensin II Stimulates Extracellular Matrix Protein Synthesis through Induction of Transforming Growth Factor- $\beta$ Expression in Rat Glomerular Mesangial Cells
}

\author{
Shoji Kagami, Wayne A. Border, Diane E. Miller, and Nancy A. Noble \\ Division of Nephrology, Department of Medicine, University of Utah School of Medicine, Salt Lake City, Utah 84132
}

\begin{abstract}
Angiotensin II (Ang II) has been implicated in the development of progressive glomerulosclerosis, but the precise mechanism of this effect remains unclear. In an experimental model, we have shown previously that TGF- $\beta$ plays a key role in glomerulosclerosis by stimulating extracellular matrix protein synthesis, increasing matrix protein receptors, and altering protease / protease-inhibitor balance, thereby inhibiting matrix degradation. We hypothesized that Ang II contributes to glomerulosclerosis through induction of TGF- $\beta$. Ang II treatment of rat mesangial cells in culture increased TGF- $\beta$ and matrix components biglycan, fibronectin, and collagen type $I$ at both the mRNA and protein levels in a time- and dose-dependent manner. Saralasin, a competitive inhibitor of Ang II, prevented the stimulation. Ang II also promoted conversion of latent TGF- $\beta$ to the biologically active form. Coincubation of mesangial cells with Ang II and neutralizing antibody to TGF- $\beta$ blocked the Ang II-induced increases in matrix protein expression. Continuous in vivo administration of Ang II to normal rats for $7 \mathrm{~d}$ resulted in $\mathbf{7 0 \%}$ increases in glomerular mRNA for both TGF- $\beta$ and collagen type I. These results indicate that Ang II induces mesangial cell synthesis of matrix proteins and show that these effects are mediated by Ang II induction of TGF- $\beta$ expression. This mechanism may well contribute to glomerulosclerosis in vivo. (J. Clin. Invest. 1994. 93:2431-2437.) Key words: fibrosis • collagen • glomerulosclerosis • kidney • proteoglycan
\end{abstract}

\section{Introduction}

Marked accumulation of mesangial matrix is a histological hallmark of progressive glomerular diseases that leads to glomerulosclerosis and end-stage kidney disease $(1,2)$. Our studies in an experimental model of glomerulonephritis induced by injection with antithymocyte serum in rats have shown that overproduction of glomerular TGF- $\beta$ can underlie the development of glomerulosclerosis (3-6). This work has been confirmed by recent studies of Isaka et al. (7) where liposomebound TGF- $\beta 1$ cDNA was introduced into rat kidneys by injection into the renal artery. Marked glomerular TGF- $\beta 1$

Address correspondence to Nancy A. Noble, Ph.D., Division of Nephrology, University of Utah School of Medicine, Salt Lake City, UT 84132.

Received for publication 29 November 1993 and in revised form 31 January 1994.

J. Clin. Invest.

(c) The American Society for Clinical Investigation, Inc.

0021-9738/94/06/2431/07 \$2.00

Volume 93, June 1994, 2431-2437 expression and matrix accumulation were seen $5 \mathrm{~d}$ after injection.

Several lines of evidence suggest that the intrarenal reninangiotensin system (RAS) ${ }^{1}$ plays an important role not only in the regulation of glomerular hemodynamics but also in glomerular growth and sclerosis (for reviews see references 8,9). Angiotensin converting enzyme inhibitors and angiotensin II (Ang II ) receptor antagonists attenuated progressive glomerulosclerosis and interstitial fibrosis in several disease models and slowed disease progression in several human studies (10-18). Elegant studies showing that glomerulosclerosis can develop and progress in the absence of glomerular hypertension, and that angiotensin converting enzyme inhibition can attenuate the progression of sclerosis without affecting the level of glomerular pressure, raise the possibility that Ang II may act directly on glomerular cells to induce sclerosis, independent of its hemodynamic action $(13,19)$. While it has been shown clearly that Ang II induces increased protein synthesis without cell proliferation in a number of kidney cell types $(9,20)$, and Ang II has been reported to stimulate mesangial cell collagen synthesis $(21,22)$, convincing data on whether Ang II induces extracellular matrix protein synthesis by glomerular cells are scarce and none exist on the mechanism of such an effect. It was reported recently that the addition of Ang II to cultured vascular smooth muscle cells stimulates secretion of TGF- $\beta(23,24)$. Since TGF- $\beta$ is clearly a potent stimulator of glomerular extracellular matrix production and deposition $(3,7,25-29)$, and since mesangial cells are similar to vascular smooth muscle cells in embryonic origin, histology, and functional properties (30), we hypothesized that Ang II induces TGF- $\beta$ production and secretion by mesangial cells and that this TGF- $\beta$ in turn stimulates extracellular matrix production and deposition. Studies were initiated using cultured rat mesangial cells where the confounding effects of Ang II on glomerular pressure were not a factor.

\section{Methods}

Cell culture. Rat mesangial cells were obtained from intact glomeruli of 4-6-wk-old Sprague-Dawley rats according to published methods and were characterized as described previously $(3,26)$. Mesangial cells were used between passages 5 and 9 and were maintained in RPMI 1640 medium (Sigma Chemical Co., St. Louis, MO) supplemented with $18 \%$ FBS (Hyclone Laboratories, Logan, UT), $100 \mathrm{U} / \mathrm{ml}$ penicillin, $100 \mu \mathrm{g} / \mathrm{ml}$ streptomycin, $0.1 \mathrm{U} / \mathrm{ml}$ insulin, and $25 \mathrm{mM}$ Hepes buffer at $37^{\circ} \mathrm{C}$ in a $5 \% \mathrm{CO}_{2}$ incubator.

Cell proliferation and protein synthesis assays. Confluent mesangial cells in 24-well culture plates (Costar Corp., Cambridge, MA) were

1. Abbreviations used in this paper: Ang II, angiotensin II; GAPDH, glyceraldehyde-3-phosphate dehydrogenase; MV1 Lu, mink lung epithelial cell; RAS, renin-angiotensin system. 
made quiescent by placing them in serum-free medium for $2 \mathrm{~d}$. They were then stimulated for 24-48 $\mathrm{h}$ with $10^{-6}-10^{-12} \mathrm{M}$ Ang II (Sigma Chemical Co.). Anderson et al. (20) have shown recently that Ang II is very stable in mesangial cell cultures under serum-free conditions. The stimulated cells were pulsed with $1 \mu \mathrm{Ci} / \mathrm{ml}\left[{ }^{3} \mathrm{H}\right.$ ] thymidine (Dupont/ New England Nuclear, Boston, MA) during the last $12 \mathrm{~h}$ of culture. Cells were washed once with PBS, twice with ice-cold 5\% TCA to remove the unincorporated $\left[{ }^{3} \mathrm{H}\right]$ thymidine, and were solubilized in 0.25 $\mathrm{N} \mathrm{NaOH}$ in $0.1 \%$ SDS and neutralized. Aliquots of samples were added to scintillation fluid and counted (Beckman Instruments, Inc., Fullerton, CA). Protein synthesis was measured by incubating cells with $\left[{ }^{35} \mathrm{~S}\right]$ methionine $(100 \mu \mathrm{Ci} / \mathrm{ml})$ (Dupont/New England Nuclear) for the last $12 \mathrm{~h}$. After labeling, media were removed, and the cells were washed once with PBS, twice with ice-cold 5\% TCA, and finally dissolved in $0.25 \mathrm{~N} \mathrm{NaOH}$ in $0.1 \%$ SDS and neutralized. Radioactivity in $10-\mu \mathrm{l}$ aliquots was counted.

$\left[{ }^{35} \mathrm{~S}\right]$ Methionine and $\left[{ }^{35} \mathrm{~S}\right]$ sulfate labeling of cells and immunoprecipitation. Confluent mesangial cells were made quiescent as described above. After $36 \mathrm{~h}$ of incubation with or without $10^{-8} \mathrm{M}$ Ang II and $10^{-5} \mathrm{M}$ saralasin (Sigma Chemical Co.), $100 \mu \mathrm{Ci} / \mathrm{ml}$ of $\left[{ }^{35} \mathrm{~S}\right]-$ methionine or $\left[{ }^{35} \mathrm{~S}\right]$ sulfate (Dupont/New England Nuclear) was added for another $12 \mathrm{~h}$. For both immunoprecipitation and proteoglycan analysis, the medium was collected and centrifuged to remove cellular debris. Immunoprecipitation experiments were performed as follows: aliquots $(100 \mu \mathrm{l})$ of the media were diluted with $900 \mu \mathrm{l}$ of RIPA buffer ( $25 \mathrm{mM}$ Tris- $\mathrm{HCl}$, pH 7.4, $150 \mathrm{mM} \mathrm{NaCl}, 0.1 \%$ SDS, $0.5 \%$ Triton X-100, $0.5 \%$ deoxycholate). Supernatants were treated sequentially with normal rabbit serum $(10 \mu \mathrm{l})$ to remove nonspecific binding, rabbit antibodies $(10 \mu \mathrm{l})$ to rat fibronectin (Telios Pharmaceuticals, Inc., San Diego, CA), and rat collagen type I (Chemicon International, Inc., Temecula, CA) for $16 \mathrm{~h}$ at $4^{\circ} \mathrm{C}$. After each antibody incubation, immune complexes were removed by the addition of protein A-Sepharose beads (Pharmacia LKB Biotechnology, Inc., Uppsala, Sweden). Beads were washed four times with RIPA buffer, and the immunoprecipitates were analyzed by electrophoresis on 4-12\% SDS-PAGE gels as described previously (3).

Quantitation of latent and active TGF- $\beta$ produced by mesangial cells in the presence of Ang II. Confluent, quiescent mesangial cells were cultured in serum-free medium containing $10^{-8} \mathrm{M}$ Ang II for 48 h. Culture supernatants were collected and dialyzed against $\alpha$-MEM (Gibco Laboratory, Grand Island, NY). The quantity of TGF- $\beta$ present in the supernatants was assayed using the mink lung epithelial cell (MV1 Lu; American Type Culture Collection, Rockville, MD) assay, where human recombinant TGF- $\beta 1$ was used to generate a standard curve (R\&D Systems, Inc., Minneapolis, MN). To determine whether mesangial cells are producing latent TGF- $\beta$, latent TGF- $\beta$ was converted to the active form by treating culture supernatants with $10 \mathrm{~N}$ $\mathrm{HCl}$ ( final $\mathrm{pH}=1.5-2.0$ ) for $30 \mathrm{~min}$ at room temperature, followed by neutralization with equimolar $\mathrm{NaOH}(29,31)$.

MV1 Lu cells were cultured in $\alpha$-MEM supplemented with $10 \%$ FBS. Bioassays were performed as described previously (24). Briefly, MV1 Lu cells were plated into 24-well culture plates in $\alpha$-MEM supplemented with $10 \%$ FBS. After a 6 -h incubation, medium was discarded, and cells were washed once with serum-free $\alpha$-MEM and then incubated with TGF- $\beta 1$ or culture supernatant in serum-free medium for $24 \mathrm{~h}$. The cells were pulsed with $\left[{ }^{3} \mathrm{H}\right]$ thymidine $(2 \mu \mathrm{Ci} / \mathrm{ml})$ for the last $6 \mathrm{~h}$, and incorporation was determined as described above. Culture supernatants were serially diluted to fall within the range of the standard curve. Specificity of the observed effects was proven by competition of the TGF- $\beta$ activity with a purified rabbit anti-TGF- $\beta$ IgG and a control IgG (R\&D Systems, Inc.).

$R N A$ analysis. Total RNA was prepared by lysis of mesangial cells in guanidine isothiocyanate solution followed by ultracentrifugation of the lysate through a cesium chloride gradient and ethanol precipitation (32). RNA concentrations were determined using spectrophotometric readings at Absorbance 260 . For Northern analysis, RNA was denatured and fractionated by electrophoresis through a $1.2 \%$ agarose gel $(20$ $\mu \mathrm{g} /$ lane) and transferred to a nylon membrane (ICN Biomedicals,
Inc., Costa Mesa, CA). Nucleic acids were immobilized by ultraviolet irradiation (Stratagene, La Jolla, CA). Membranes were prehybridized with $50 \%$ formamide, $10 \%$ Denhardts solution, $0.1 \%$ SDS, $5 \times$ SSC, and $200 \mu \mathrm{g} / \mathrm{ml}$ denatured salmon sperm DNA and hybridized with DNA probes labeled with ${ }^{32} \mathrm{P}$-dCTP by random oligonucleotide priming (Boehringer Mannheim Corp., Indianapolis, IN). The blots were washed in $2 \times$ SSC, $0.1 \%$ SDS at room temperature for $15 \mathrm{~min}$ and in $0.1 \times \mathrm{SSC}, 0.1 \% \mathrm{SDS}$ at $55^{\circ} \mathrm{C}$ for $30 \mathrm{~min}$. In addition to ethidium bromide staining, autoradiographic signals obtained with the rat glyceraldehyde-3-phosphate dehydrogenase (GAPDH) cDNA probe served as controls for equal loading of the gel. Autoradiographs were scanned on an laser densitometer (Ultrascan XL; Pharmacia LKB Biotechnology, Inc.). Changes in mRNA levels were determined by first correcting for the densitometric intensity of GAPDH for each sample. For comparison, this ratio was set at unity for normal control samples, or samples at zero time and other lanes on the same gel were expressed as fold increases over this value.

$c D N A$ probes. A mouse TGF- $\beta 1$ cDNA probe (plasmid MUI5) was provided kindly by R. Derynck (33). Plasmid P16, which contains a human biglycan insert, was a kind gift of L. W. Fisher (34). A rat procollagen $\alpha_{1}$ cDNA (plasmid pa1R1) was a gift from D. Rowe (35), and a rat GAPDH cDNA probe was a gift from M. B. Sporn (36). A 24-bp oligonucleotide probe was prepared from a rat fibronectin sequence as follows. Total RNA from rat glomeruli was reversely transcribed, and the subsequent cDNA was amplified using fibronectinspecific primers. The specificity of the fibronectin cDNA was verified by Southern blot analysis.

In vivo administration of Ang II. Miniosmotic pumps (model 2ML4; Alza Corp., Palo Alto, CA) were implanted subcutaneously into eight normal Sprague-Dawley rats. Four pumps contained Ang II dissolved in $0.01 \mathrm{~N}$ acetic acid for in vivo delivery of $100 \mathrm{ng} / \mathrm{min}$. Four pumps contained $0.01 \mathrm{~N}$ acetic acid alone. This dose of Ang II has been shown to produce substantial glomerulosclerosis by $12 \mathrm{wk}$ of treatment (37). After $1 \mathrm{wk}$, RNA was obtained as described above from glomeruli isolated by previously published methods (3).

Statistical analysis. Results are presented as mean \pm SD. Statistical significance was determined using Student $t$ tests. Triplicate wells were analyzed for each experiment, and each experiment was performed independently a minimum of three times.

\section{Results}

Effect of Ang II on mRNA levels for TGF- $\beta$ and matrix components. Incubation of quiescent mesangial cells with $10^{-6} \mathrm{M}$ Ang II and subsequent Northern blot analysis revealed increased mRNA levels for TGF- $\beta$ and extracellular matrix proteins (Fig. 1). Expression of TGF- $\beta$ was weakly detected in quiescent mesangial cells (time 0 ). However, $4 \mathrm{~h}$ after Ang II treatment, TGF- $\beta$ mRNA was elevated significantly by more than threefold $(P<0.01)$. This increase peaked at $8 \mathrm{~h}$ with a sixfold increase, and at $48 \mathrm{~h}$ TGF- $\beta$ message was still threefold elevated compared with control $(P<0.01)$. Message for the three extracellular matrix proteins measured, which are known to be induced by TGF- $\beta$, all showed progressive increases with time from the first time point of $4 \mathrm{~h}$ until $48 \mathrm{~h}$ when the experiment was terminated. Biglycan, fibronectin, and collagen type I transcripts were increased significantly by $8 \mathrm{~h}(P<0.05)$ and remained elevated, showing 4.9-, 4.3-, and 2.8-fold increases, respectively, at $48 \mathrm{~h}$ (Fig. $1 ; P<0.05$ ). When the response of these transcripts to Ang II dose was investigated after $24 \mathrm{~h}$ of incubation, it was seen that each responded in a dose-dependent manner between $10^{-12}$ and $10^{-6} \mathrm{M}$ (Fig. 2). At $10^{-6} \mathrm{M}$ Ang II, all transcripts were elevated significantly over control values $(P<0.01)$. The results of treatment of cells with saralasin, which acts as a competitive inhibitor of Ang II receptor 


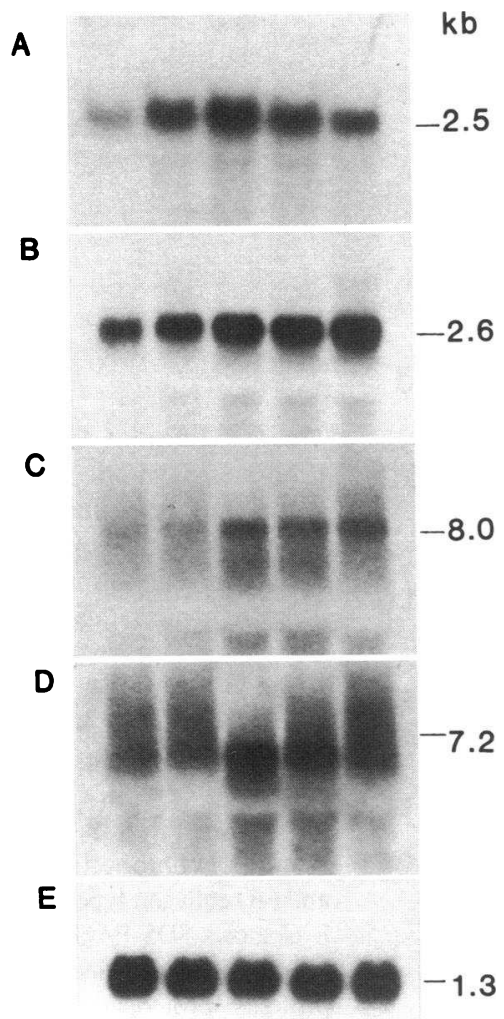

$\begin{array}{lllll}0 & 4 & 8 & 24 & 48\end{array}$

Hours
Figure 1. Northern blot of mRNA from quiescent mesangial cells treated with $10^{-6} \mathrm{M}$ Ang II for increasing times. $A$, TGF- $\beta ; B$, biglycan; $C$, fibronectin; $D$, collagen type I; and $E$, GAPDH. Results are representative of triplicate experiments. Molecular size markers are shown on the right.

binding, are shown in Fig. 3. While $10^{-5} \mathrm{M}$ saralasin had no significant effect on mRNA levels in the absence of Ang II, it dramatically decreased the Ang II-induced increases. With the

A

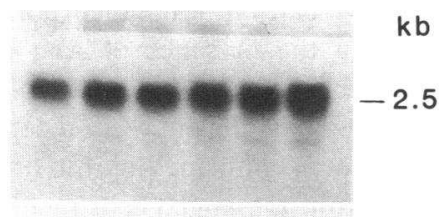

B
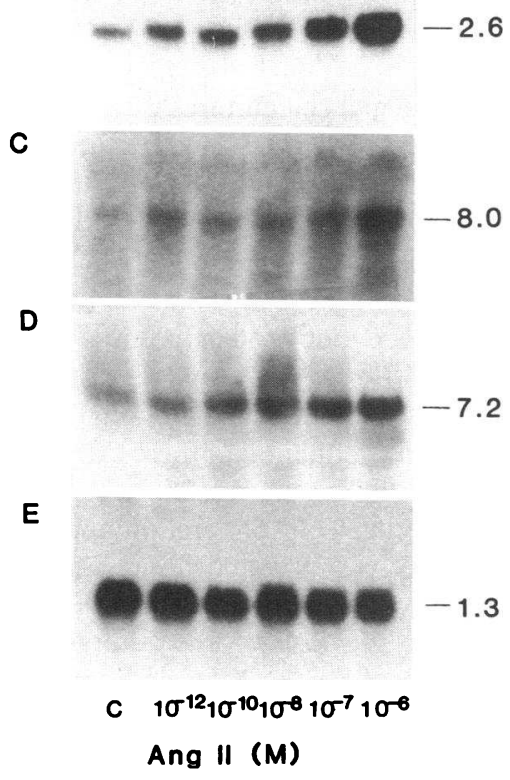
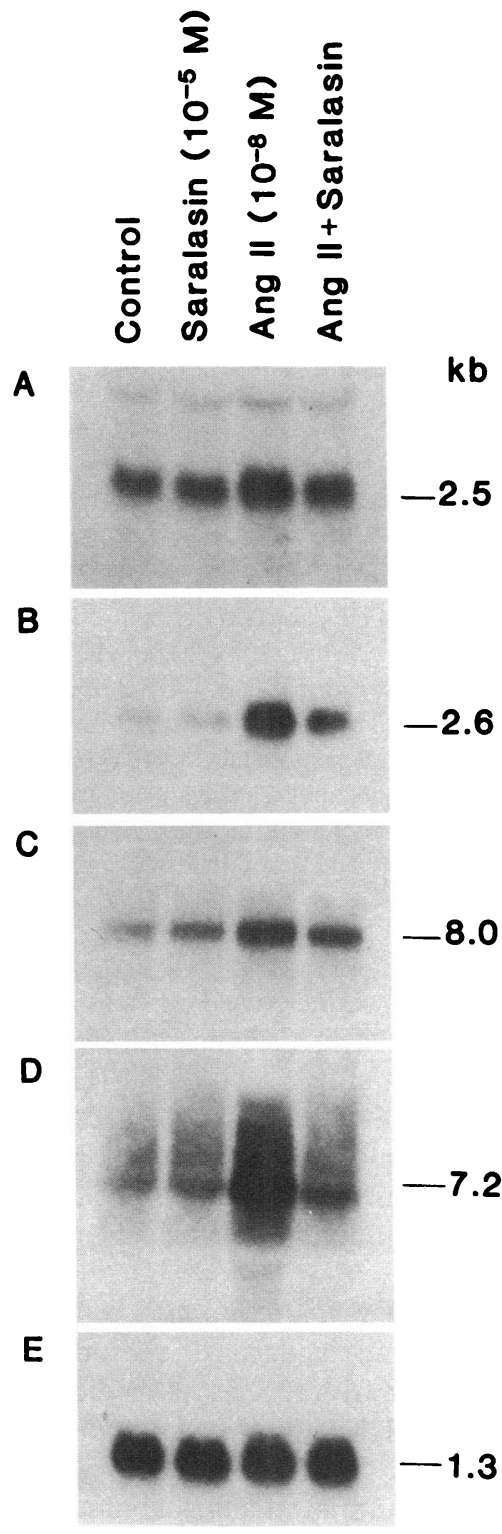

Figure 3. Northern blot of effect of saralasin on Ang II-induced increases in mesangial cell mRNA. $A$, TGF- $\beta ; B$, biglycan; $C$, fibronectin; $D$, collagen type I; and $E$, GAPDH. Results are representative of triplicate experiments. Molecular size markers are shown on the right.

exception of biglycan mRNA, which remained significantly elevated over controls, mRNA levels in the presence of saralasin were not statistically elevated over controls. These results indicate that the observed Ang II effects are receptor mediated (Fig. 3).

Effect of Ang II on TGF- $\beta$ activity of mesangial cell cultures. To establish that the rise in TGF- $\beta$ mRNA in mesangial cell culture was accompanied by the synthesis of active or latent forms of TGF- $\beta$ protein, TGF- $\beta$ activity was measured by using the standard MV 1 Lu cell bioassay, where TGF- $\beta$ secreted by mesangial cells into culture medium is measured by its ability to inhibit cell growth. Fig. 4 shows that the mean active TGF- $\beta$ present in six control mesangial cell cultures was 0.24 $\mathrm{ng} / \mathrm{ml}$ (Fig. 4, open bar). When stimulated with $10^{-8} \mathrm{M}$ Ang II, a 12 -fold increase to $2.9 \mathrm{ng} / \mathrm{ml}$ was seen (Fig. $4, P<0.001$ ). This increased activity was completely abrogated by neutralizing anti-TGF- $\beta$ antibody (Fig. 4, black bar), but not by nonimmune rabbit IgG (data not shown). Acid treatment of conditioned medium resulted in significant increases in active TGF- $\beta$ in both control and Ang II-treated cultures $(P<0.05)$. However, acid treatment of control conditioned medium re- 


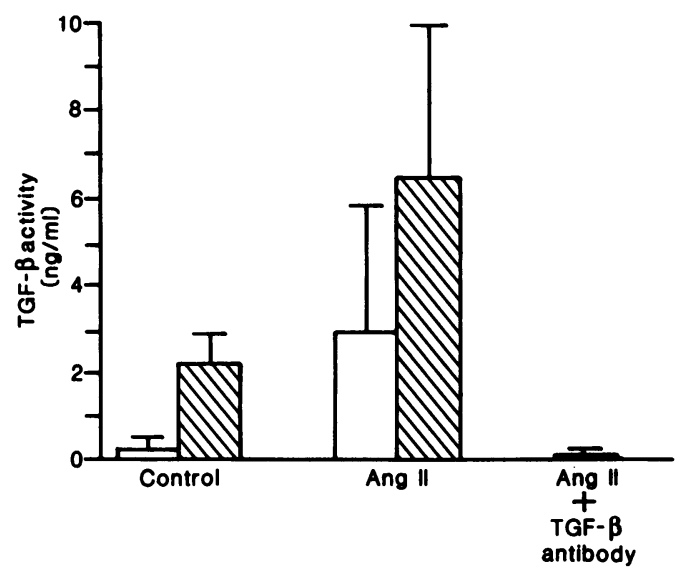

Figure 4. Effect of $10^{-8} \mathrm{M}$ Ang II on TGF- $\beta$ bioactivity before and after acidification of culture medium as measured by the standard MV1 Lu bioassay. Open bars represent mean \pm SD of TGF- $\beta$ in culture supernatant from six mesangial cell cultures stimulated with and without $10^{-8} \mathrm{M}$ Ang II. Hatched bars represent mean \pm SD of TGF- $\beta$ activities of the same culture supernatants after transient acidification to activate latent TGF- $\beta$. The black bar represents the mean \pm SD of TGF- $\beta$ activities in the presence of both Ang II and neutralizing antibody to TGF- $\beta$.

sulted in $2.1 \mathrm{ng} / \mathrm{ml}$ active TGF- $\beta$, while active TGF- $\beta$ in Ang II-treated cultured media increased to $6.35 \mathrm{ng} / \mathrm{ml}$ (Fig. 4, hatched bars). Thus, an average of only $11 \%$ of the total TGF- $\beta$ in control cultures was active, while $45 \%$ of the total TGF- $\beta$ in Ang II-treated cultures was active $(P<0.05)$. This result indicates that Ang II increased not only the production of both latent and active TGF- $\beta$ but also stimulated the conversion of latent to active TGF- $\beta$ (Fig. 4).

Effect of Ang II on mesangial cell synthesis of matrix components. Equal amounts of $\left[{ }^{35} \mathrm{~S}\right]$ methionine-labeled conditioned medium were immunoprecipitated with specific antibodies to fibronectin and collagen type I. $\left[{ }^{3} \mathrm{H}\right]$ Thymidine incorporation did not differ between Ang II-treated and control cultures, indicating that this represented medium from an equal number of cells ( see Fig. $6 B$ citation below). Consistent with the results of Northern blot analysis with or without saralasin (Fig. 3), immunoprecipitated fibronectin and collagen type I were significantly increased by $10^{-8} \mathrm{M}$ Ang II 4.1- and 3.5-fold over controls, respectively (Fig. 5, $A$ and $B ; P<0.01$ ). Similarly, when conditioned medium from $\left[{ }^{35} S\right]$ sulfate-labeled mesangial cell cultures was subjected to SDS-PAGE and fluorography, a 2.4fold increase in sulfate-labeled proteins was seen with $10^{-8} \mathrm{M}$ Ang II treatment for $48 \mathrm{~h}$ (Fig. $5 C ; P<0.01$ ). Concomitant incubation with $10^{-5} \mathrm{M}$ saralasin and $10^{-8} \mathrm{M}$ Ang II markedly reduced the levels of Ang II-stimulated synthesis of these proteins and proteoglycans so that the quantity immunoprecipitated or electrophoresed did not differ from that obtained from control conditioned medium (Fig. 5).

Effect of coincubation with TGF- $\beta$ antibody in Ang II-stimulated mesangial cell culture. To assess whether secreted TGF$\beta$ protein mediated the effects of Ang II on the expression of matrix proteins, Ang II-treated mesangial cells were coincubated with TGF- $\beta$ neutralizing antibody $(100 \mu \mathrm{g} / \mathrm{ml})$ or control IgG $(100 \mu \mathrm{g} / \mathrm{ml})$. As reported previously (20), mesangial cell treatment with $10^{-8} \mathrm{M}$ Ang II stimulates protein synthesis but not cell replication (Fig. 6). Treatment of cultures with neutralizing antibody significantly, but not completely,

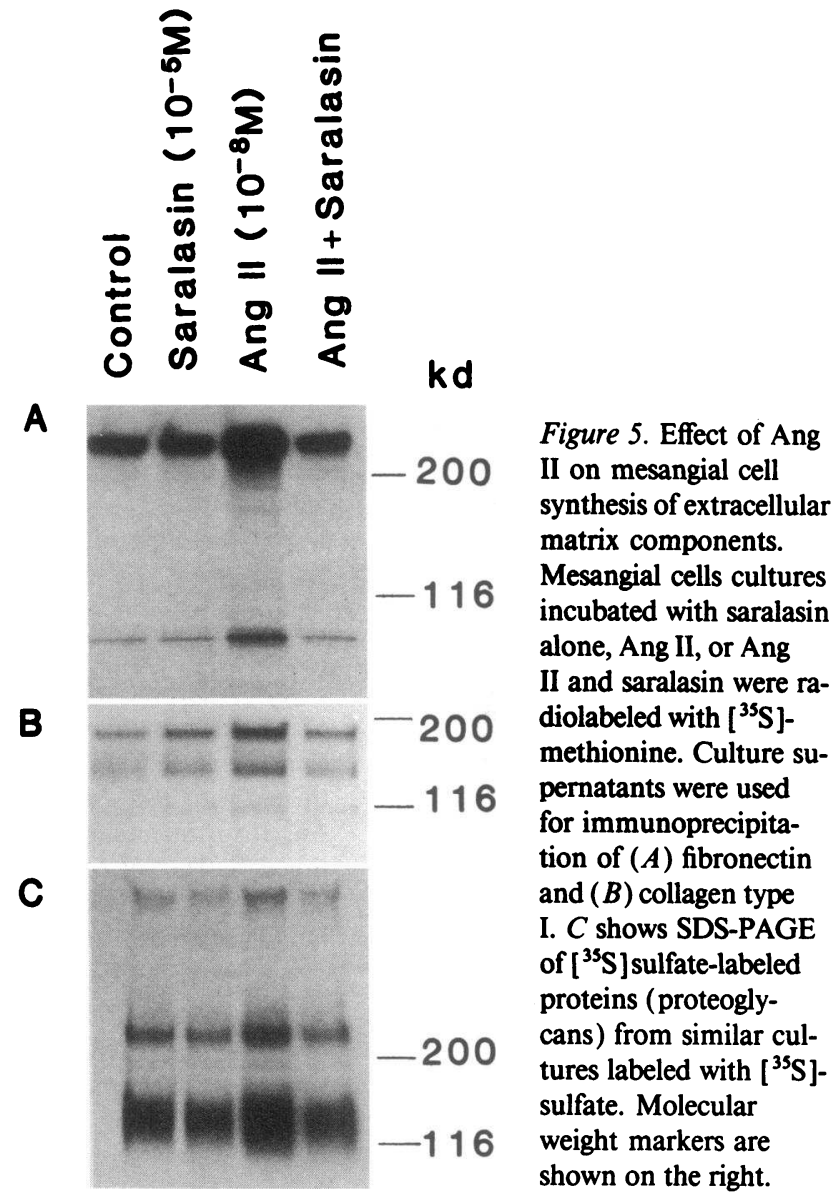

blocked the stimulation of protein synthesis observed at $48 \mathrm{~h}$ $(P<0.05)$ (Fig. $6 A)$. In contrast, addition of neutralizing antibody significantly increased $\left[{ }^{3} \mathrm{H}\right]$ thymidine incorporation of mesangial cells incubated in the presence of Ang II ( $P$ $<0.05$ ), indicating increased cell proliferation. Control IgG had no effect (Fig. $6 B$ ). The fact that sufficient TGF- $\beta$ neutralizing antibody had been added was confirmed by the finding that the conditioned medium from mesangial cells incubated with Ang II and TGF- $\beta$ neutralizing antibody for $48 \mathrm{~h}$ contained control levels of TGF- $\beta$ activity $(0.15 \mathrm{ng} / \mathrm{ml})$ as measured by bioassay.

When antibody-treated mesangial cell cultures were radiolabeled with $\left[{ }^{35} \mathrm{~S}\right]$ methionine or $\left.{ }^{35} \mathrm{~S}\right]$ sulfate, and culture supernatant was either immunoprecipitated or subjected to SDSPAGE, the results seen in Fig. 7 were obtained. While addition of neutralizing antibody to TGF- $\beta$ (Fig. 7, lane 2) and control IgG (Fig. 7, lane 3) had no effect on the synthesis of fibronectin (Fig. $7 \mathrm{~A}$ ), collagen type I (Fig. $7 \mathrm{~B}$ ), or proteoglycans (Fig. 7 $C$ ), neutralizing antibody to TGF- $\beta$ (Fig. 7, lane 5) but not control antibody (Fig. 7, lane 6) greatly reduced the Ang II-induced increases (Fig. 7, lane 4) in production of these extracellular matrix components to levels that did not differ statistically from controls. Thus, autocrine TGF- $\beta$ secretion appears to mediate a large portion of the Ang II-induced increases in production of matrix proteins by mesangial cell cultures.

Ang II administration in vivo. Fig. 8 shows the results of in vivo administration of Ang II on the mRNA levels from isolated glomeruli for TGF- $\beta 1$ and collagen type I. After only $1 \mathrm{wk}$ of treatment, a significant increase in mRNA for both proteins 

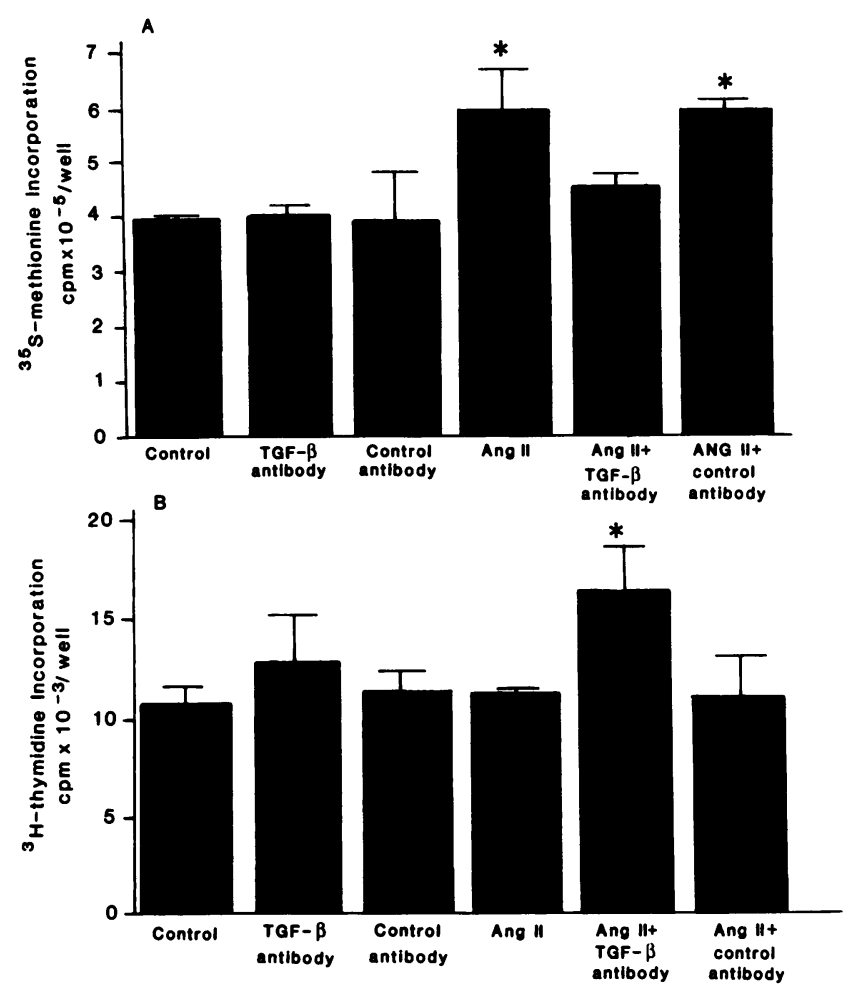

Figure 6. Effect of coincubation of Ang II and neutralizing antibody to TGF- $\beta$ on protein synthesis and cell proliferation. Radioactivity precipitated by TCA from mesangial cells incubated under conditions described in Methods. $A,\left[{ }^{35} \mathrm{~S}\right]$ Methionine radioactivity; $B,\left[{ }^{3} \mathrm{H}\right]-$ thymidine.

is seen (Fig. 8, $A$ and $B ; P<0.01$ ). When corrected for the housekeeping enzyme GAPDH (Fig. $8 C$ ) and plotted, it is seen that TGF- $\beta 1$ message is 1.7 -fold and collagen type I message is 1.8 -fold increased by Ang II (Fig. $8 D$ ).

\section{Discussion}

Our laboratory has shown that in a rat model of acute glomerulonephritis, TGF- $\beta$ is a critical determinant of matrix synthesis, matrix degradation, and glomerular expression of integrin receptors which mediate matrix deposition (3-6). A recent report, where TGF- $\beta 1$ was transiently expressed in normal rat glomeruli using in vivo gene transfection, has dramatically confirmed that TGF- $\beta$ alone can produce marked glomerulosclerosis (7). Recent human studies have shown that the level of glomerular TGF- $\beta$ expression correlates with the degree of mesangial matrix expansion in IgA nephropathy and in other glomerular diseases characterized by accumulation of pathological matrix $(38,39)$.

Ang II has also been implicated in pathological matrix accumulation in several different animal models of progressive glomerulosclerosis and in patients with chronic renal diseases. Angiotensin converting enzyme inhibitors, which block Ang II generation, have been shown to attenuate or even reverse the development of sclerosis (10-18). The question of whether Ang II leads to increased matrix protein synthesis directly or whether these effects are solely secondary to increased intraglomerular pressure was addressed using mesangial cells in culture where the effects of increased intraglomerular pressure are absent (40). Our hypothesis was that Ang II has a direct effect on

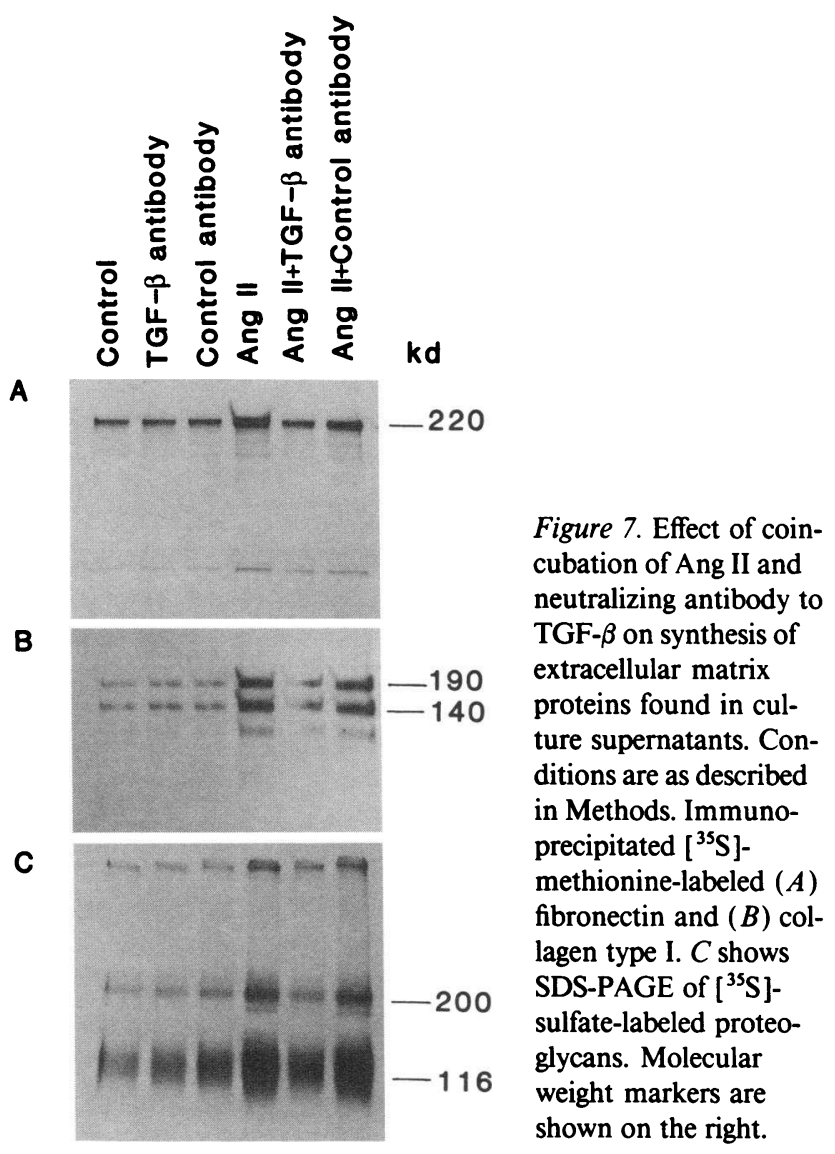

TGF- $\beta$ production. This hypothesis is consistent with recent data showing that Ang II stimulates the expression of TGF- $\beta 1$ in vascular smooth muscle cell cultures $(23,24)$. We further hypothesized that the TGF- $\beta$ produced in response to Ang II treatment stimulates production of matrix components which lead to pathological matrix accumulation. This is consistent with several brief reports that Ang II stimulates collagen production in cultured rat mesangial cells $(21,22)$. We evaluated the matrix components fibronectin, collagen type I and biglycan which are known to be increased by TGF- $\beta$ and which are associated with the process of sclerosis $(34,35,41,42)$.

The data presented support our hypotheses. Ang II increases the level of TGF- $\beta$ mRNA and increases production of both latent and active TGF- $\beta$. Similar to the findings of Wolf et al. (43) with proximal tubular cells, Gibbons et al. (44) using vascular smooth muscle cells, and Anderson et al. (20) using mesangial cells, we found that Ang II-treated mesangial cells show hypertrophy but not hyperplasia(Fig. 6). When neutralizing antibody to TGF- $\beta$ and Ang II were added together, a significant increase in cell proliferation was seen consistent with the idea that Ang II may influence the biological action of TGF- $\beta$ in vivo.

Our data also show that Ang II treatment leads to an increase in the conversion of latent to active TGF- $\beta$ as it does in vascular smooth muscle cells (44). It was shown recently that plasmin generated by the action of plasminogen activator is required for the activation of latent TGF- $\beta$ in cell culture studies (45). Ang II is known to increase cell-associated plasminogen activator in vascular smooth muscle cell cultures (46) and similarly may stimulate mesangial cell synthesis of plasmino- 


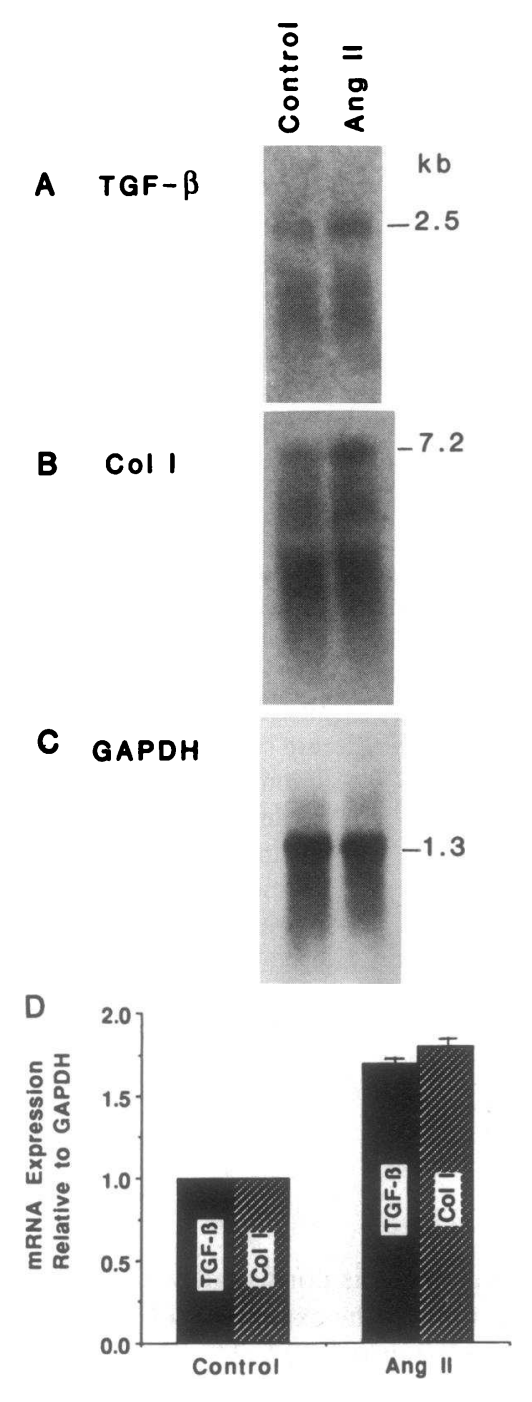

Figure 8. Effect of continuous in vivo administration of $100 \mathrm{ng}$ Ang II/min to normal rats for 1 wk on glomerular mRNA for TGF- $\beta$ and collagen type I ( $\mathrm{Col} \mathrm{I)}$. Molecular size markers are shown on the right.

gen activator, generation of plasmin, and conversion of latent to biologically active TGF- $\beta$.

In addition to confirming that the growth response to Ang II is mediated by increased TGF- $\beta$ production and that Ang II treatment leads to increased conversion of latent to active TGF- $\beta$, these studies make the original contribution that links Ang II to production of pathological matrix proteins at both the mRNA and protein level through induction of TGF- $\beta$. These molecular responses to Ang II are dose dependent and since they can be blocked by the Ang II receptor blocker, saralasin, they are specific. The Ang II-induced levels of active TGF- $\beta$ are well within the range needed to increase matrix protein synthesis $(25,26)$. The increase in mRNA for matrix components is somewhat delayed compared with induction of TGF- $\beta$ mRNA (Fig. 1), consistent with the hypothesis that the Ang II effects on matrix protein synthesis are indirect and depend upon autocrine secretion of TGF- $\beta$ by mesangial cells. This hypothesis was confirmed by addition of neutralizing antibody to TGF- $\beta$ (Fig. 7). These results support the existence of a molecular cascade where Ang II stimulates the production and secretion of active TGF- $\beta$ and this TGF- $\beta$ in turn stimulates synthesis and deposition of matrix components.

Although Ang II concentrations in normal rat glomerular filtrate have been reported to be $\sim 10^{-8} \mathrm{M}$ and therefore well within the range we used in these experiments (47), until re-

cently tools were not available to determine the role of the intrarenal RAS in disease and under various therapeutic strategies. Studies have now shown that all components of the intrarenal RAS are present in human kidney (48), and studies using animal models are now appearing. Rosenberg et al. (49) reported that low protein diet but not uninephrectomy decreases renal renin mRNA but does not change either renal or liver angiotensinogen mRNA expression. Anderson et al. (50) demonstrated increases in intrarenal renin protein content and expression of mRNAs for renin and angiotensin converting enzyme in streptozotocin-induced diabetic rats, suggesting activation of intrarenal RAS in diabetes. Total renal angiotensin converting enzyme activity, however, was reduced, but immunohistochemical staining revealed redistribution of angiotensin converting enzyme protein, with increased staining intensity in glomeruli. We have shown previously that low protein diet suppresses TGF- $\beta$ expression and extracellular matrix deposition in experimental glomerulonephritis (51). We have further shown that increases in TGF- $\beta$ expression are correlated with matrix accumulation in streptozotocin diabetes (38). Therefore, our previous studies, the data presented here, and those of Rosenberg et al. (49) and Anderson et al. (50) are all consistent with a role for glomerular Ang II-induced and TGF- $\beta$-mediated alterations in extracellular matrix production and deposition.

In conclusion, by studying the response of mesangial cells in culture to exogenously added Ang II, we have shown that Ang II may play an important role in the sclerotic changes within the glomerulus independent of changes brought about by increased glomerular pressure. We have further shown that these effects are mediated through Ang II induction of TGF- $\beta$ synthesis and secretion. A large body of work now exists showing that TGF- $\beta$ is a key fibrogenic cytokine in diseases of liver, lung, and central nervous system as well as in the kidney (27). The data presented raise the possibility that, when the systemic and/or intrarenal RAS is once activated under pathological conditions such as systemic hypertension and chronic renal disease, both intraglomerular hypertension and activation of TGF- $\beta$ exert additive effects on accumulation of extracellular matrix and progression of glomerular injury.

\section{Acknowledgments}

We wish to thank Markus Ketteler for his helpful comments.

This study was supported by grant DK-43609 to W. A. Border from the National Institute of Diabetes, Digestive and Kidney Diseases.

\section{References}

1. Klahr, S., G. Schreiner, and I. Ichikawa. 1988. The progression of renal disease. N. Engl. J. Med. 318:1657-1666.

2. Kashgarian, M., and R. B. Sterzel. 1992. The pathobiology of the mesangium. Kidney Int. 41:524-529.

3. Okuda, S., L. R. Languino, E. Ruoslahti, and W. A. Border. 1990. Elevated expression of transforming growth factor- $\beta$ and proteoglycan production in experimental glomerulonephritis. Possible role in expansion of the mesangial extracellular matrix. J. Clin. Invest. 86:453-462.

4. Border, W. A., S. Okuda, L. R. Languino, M. B. Sporn, and E. Ruoslahti. 1990. Suppression of experimental glomerulonephritis by antiserum against transforming growth factor- $\beta 1$. Nature (Lond.). 346:371-374.

5. Tomooka, S., W. A. Border, B. C. Marshall, and N. A. Noble. 1992. Glomerular matrix accumulation is linked to inhibition of the plasmin protease system. Kidney Int. 42:1462-1469.

6. Kagami, S., W. A. Border, E. Ruoslahti, and N. A. Noble. 1993. Coordinated expression of $\beta 1$ integrins and TGF- $\beta$-induced matrix proteins in glomerulonephritis. Lab. Invest. 69:68-76. 
7. Isaka, Y., Y. Fujiwara, N. Ueda, Y. Kaneda, T. Kamada, and E. Imai. 1993. Glomerulosclerosis induced by in vivo transfection of transforming growth factor- $\beta$ or platelet-derived growth factor gene into the rat kidney. J. Clin. Invest. 92:2597-2601.

8. Ichikawa, I., and R. C. Harris. 1991. Angiotensin actions in the kidney: renewed insight into the old hormone. Kidney Int. 40:583-596.

9. Wolf, G., and E. G. Neilson. 1993. Angiotensin II as a renal growth factor. J. Am. Soc. Nephrol. 3:1531-1540.

10. Pelayo, J. C., M. G. Ziegler, and R. C. Blantz. 1984. Angiotensin II in adrenergic-induced alterations in glomerular hemodynamics. Am. J. Physiol. 247:F799-F807.

11. Anderson, S., T. W. Meyer, H. G. Rennke, and B. M. Brenner. 1985. Control of glomerular hypertension limits glomerular injury in rats with reduced renal mass. J. Clin. Invest. 76:612-619.

12. Fogo, A., Y. Yoshida, A. D. Glick, T. Homma, and I. Ichikawa. 1988. Serial micropuncture analysis of glomerular function in two rat models of glomerular sclerosis. J. Clin. Invest. 82:322-330.

13. Yoshida, Y., T. Kawamura, M. Ikomo, A. Fogo, and I. Ichikawa. 1989 Effects of antihypertensive drugs on glomerular morphology. Kidney Int. 36:626635.

14. Diamond, J. R., and S. Anderson. 1990. Irreversible tublointerstitial damage associated with chronic aminonucleoside nephrosis. Am. J. Pathol 137:1323-1332.

15. Lafayette, R. A., G. Mayer, S. K. Park, and T. W. Meyer. 1992. Angiotensin II receptor blockade limits glomerular injury in rats with reduced renal mass. J. Clin. Invest. 90:766-771.

16. Reams, G. P., and J. H. Bauer. 1986. Enalapril in subjects with renal disease. J. Hypertens. 4:S417-S419.

17. Keane, W. F., S. Anderson, M. Aurell, D. de Zeeuw, R. G. Narins, and G. Povar. 1989. Angiotensin converting enzyme inhibitors and progressive renal insufficiency. Ann. Intern. Med. 111:503-516.

18. Ravid, M., H. Savin, I. Jutrin, T. Bental, B. Katz, and M. Lishner. 1993. Long term stabilizing effect of angiotensin-converting enzyme inhibition on plasma creatinine and on proteinuria in normotensive type II diabetic patients. Ann. Intern. Med. 118:577-581.

19. Kakinuma, Y., T. Kawamura, T. Bills, T. Yoshioka, I. Ichikawa, and A Fogo. 1992. Blood pressure-independent effect of angiotensin inhibition on vascular lesions of chronic renal failure. Kidney Int. 42:46-55.

20. Anderson, P. W., Y. S. Do, and W. A. Hsueh. 1993. Angiotensin II causes mesangial cell hypertrophy. Hypertension (Dallas). 21:29-35.

21. Homma, T., R. L. Hoover, I. Ichikawa, and R. C. Harris. 1990. Angiotensin II induces hypertrophy and stimulates collagen production in cultured rat mesangial cell. Clin. Res. 38:358a. (Abstr.)

22. Wolf, G., U. Haberstroh, and E. G. Neilson. 1992. Angiotensin II stimulates the proliferation and biosynthesis of type I collagen in cultured murine mesangial cells. Am. J. Pathol. 140:95-107.

23. Naftilan, A. J., R. E. Paratt, and V. J. Dzau. 1989. Induction of plateletderived growth factor A-chain and c-myc gene expressions by angiotensin II in cultured rat vascular smooth muscle cells. J. Clin. Invest. 83:1419-1424.

24. Itoh, H., M. Mukoyama, R. E. Pratt, G. H. Gibbons, and V. J. Dzau. 1993. Multiple autocrine growth factors modulate vascular smooth muscle cell growth responses to angiotensin II. J. Clin. Invest. 91:2268-2274.

25. MacKay, K., L. J. Striker, J. W. Stauffer, T. Doi, L. Y. Agodoa, and G. E. Striker. 1989. Transforming growth factor- $\beta$. Murine glomerular receptors and responses of isolated glomerular cells. J. Clin. Invest. 83:1160-1167.

26. Border, W. A., S. Okuda, L. R. Languino, and E. Ruoslahti. 1990. Transforming growth factor- $\beta$ regulates production of proteoglycans by mesangial cells. Kidney Int. 37:689-695.

27. Border, W. A., and E. Ruoslahti. 1992. Transforming growth factor- $\beta$ in disease: The dark side of tissue repair. J. Clin. Invest. 90:1-7.

28. Wolf, G., K. Sharma, Y. Chen, M. Ericksen, and F. N. Ziyadeh. 1992. High glucose-induced proliferation in mesangial cells is reversed by autocrine TGF- $\beta$. Kidney Int. 42:647-656.

29. Kaname, S., S. Uchida, E. Ogata, and K. Kurokawa. 1992. Autocrine secretion of transforming growth factor- $\beta$ in cultured rat mesangial cells. Kidney Int. 42:1319-1327.

30. Schlondorff, D. 1987. The glomerular mesangial cell: an expanding role for a specialized pericyte. FASEB (Fed. Am. Soc. Exp. Biol.) J. 1:272-281.
31. Lyons, R. M., J. Keski-Oja, and H. L. Moses. 1988. Proteolytic activation of latent transforming growth factor $\beta$ from fibroblast-conditioned medium. $J$. Cell Biol. 106:1659-1665.

32. Sambrook, J., E. F. Fritsch, and T. Maniatis. 1989. Molecular Cloning: A Laboratory Manual. 2nd ed. Cold Spring Harbor Laboratory, Cold Spring Harbor, NY. 1,648 pp.

33. Derynck, R., J. A. Jarrett, E. Y. Chen, and D. V. Goeddel. 1986. The murine transforming growth factor- $\beta$ precursor. J. Biol. Chem. 261:4377-4379.

34. Fisher, L. W., J. D. Termine, and M. F. Young. 1989. Deduced protein sequence of small proteoglycan I (biglycan) shows homology with proteoglycan II (decorin) and several nonconnective tissue proteins in a variety of species. $J$. Biol. Chem. 264:4571-4576.

35. Genovese, C., D. Rowe, and B. Kream. 1984. Construction of DNA sequences complementary to rat $\alpha 1$ and $\alpha 2$ collagen mRNA and their use in studying the regulation of type I collagen synthesis by 1,25-dehydroxyvitamin $\mathrm{D}$. Biochemistry. 23:6210-6216.

36. Fort, Ph., L. Marty, M. Piechaczyk, S. El. Sabrouty, Ch. Dani, Ph. Jeanteur, and J. M. Blanchard. 1985. Various rat adult tissues express only one major mRNA species from the glyceraldehyde-3-phosphate-dehydrogenase multigenenic family. Nucleic Acids Res. 13:1431-1443.

37. Miller, P. L., H. G. Rennke, and T. W. Meyer. 1991. Glomerular hypertrophy accelerates hypertensive glomerular injury in rats. Am. J. Physiol. 261:F459-F465.

38. Yamamoto, T., T. Nakamura, N. A. Noble, E. Ruoslahti, and W. A Border. 1993. Expression of transforming growth factor $\beta$ is elevated in human and experimental diabetic nephropathy. Proc. Natl. Acad. Sci. USA. 90:18141818.

39. Yoshioka, K., T. Takemura, K. Murakami, M. Okada, S. Hino, H. Miyamato, and S. Maki. 1993. Transforming growth factor- $\beta$ protein and mRNA in glomeruli in normal and diseased human kidneys. Lab. Invest. 68:154-163.

40. Riser, B. L., P. Cortes, X. Zhao, J. Bernstein, F. Dumler, and R. G. Narins. 1992. Intraglomerular pressure and mesangial stretching stimulate extracellular matrix formation in the rat. J. Clin. Invest. 90:1932-1943.

41. Oomura, A., T. Nakamura, M. Arakawa, A. Ooshima, and M. Isemura 1989. Alterations in the extracellular matrix components in human glomerular diseases. Virchows Archiv. A Pathol. Anat. Histol. 415:151-159.

42. Ebihara, I., S. Suzuki, T. Nakamura, M. Fukui, Y. Yaguchi, Y. Tomino, and H. Koide. 1993. Extracellular matrix component mRNA expression in glomeruli in experimental focal glomerulosclerosis. J. Am. Soc. Nephrol. 3:13871397.

43. Wolf, G., and E. G. Neilson. 1990. Angiotensin II induces cellular hypertrophy in cultured murine proximal tubular cells. Am. J. Physiol. 259:F768F777.

44. Gibbons, G. H., R. E. Pratt, and V. J. Dzau. 1992. Vascular smooth muscle cell hypertrophy vs. hyperplasia. J. Clin. Invest. 90:456-461.

45. Flaumenhaft, R., M. Abe, P. Mignatti, and D. B. Rifkin. 1992. Basic fibroblast growth factor-induced activation of latent transforming growth factor $\beta$ in endothelial cells: regulation of plasminogen activator activity. J. Cell Biol. 118:901-909.

46. Bell, L., and J. A. Madri. 1990. Influence of the angiotensin system on endothelial and smooth muscle cell migration. Am. J. Pathol. 137:7-12.

47. Seikaly, M. G., B. S. Arant, Jr., and F. D. Seney, Jr. 1990. Endogenous angiotensin concentrations in specific intrarenal fluid compartments of the rat. $J$. Clin. Invest. 86:1352-1357.

48. Paul, M., J. Wagner, and V. J. Dzau. 1993. Gene expression of the reninangiotensin system in human tissues. Quantitative analysis by the polymerase chain reaction. J. Clin. Invest. 91:2058-2064.

49. Rosenberg, M. E., D. Chmielewski, and T. H. Hostetter. 1990. Effect of dietary protein on rat renin and angiotensinogen gene expression. J. Clin. Invest. 85:1144-1149.

50. Anderson, S., F. F. Jung, and J. R. Ingelfinger. 1993. Renal renin-angiotensin system in diabetes: functional, immunohistochemical, and molecular biological correlations. Am. J. Physiol. 265:F477-F486

51. Okuda, S., T. Nakamura, T. Yamamoto, E. Ruoslahti, and W. A. Border. 1991. Dietary protein restriction rapidly reduces transforming growth factor $\beta 1$ expression in experimental glomerulonephritis. Proc. Natl. Acad. Sci. USA. 88:9765-9769. 